\title{
Dynamics of diethyllead excretion in the urine of rabbits after tetraethyllead administration
}

\author{
Z KOZARZEWSKA, ${ }^{1}$ J CHMIELNICKA ${ }^{2}$
}

From the Department of Metabolism of Toxic Compounds, ${ }^{1}$ Institute of Occupational Medicine, and Department of Toxicological Chemistry, ${ }^{2}$ Institute of Environmental Research and Bioanalysis, Medical Academy, Lódź, Poland

ABSTRACT The dynamics of diethyllead excretion in rabbit urine according to the dose and method of administration of tetraethyllead were studied. Investigations were made on male rabbits which were given two doses of tetraethyllead $(12 \mathrm{mg} / \mathrm{kg}$ and $3 \mathrm{mg} / \mathrm{kg})$ using intravenous and intragastric methods. Rabbits were also exposed for five hours to tetraethyllead at a concentration of $200 \mu \mathrm{g} / \mathrm{m}^{3}$ in the air. The results show the relation of the diethyllead excretion in rabbit urine to the dose and method of administration.

A method for determining diethyllead $\left(\mathrm{Et}_{2} \mathrm{~Pb}^{+2}\right)$ in urine published recently showed that this compound is a specific indicator not only for assessing acute intoxication ${ }^{1}$ but also for evaluating occupational exposure to tetraethyllead $\left(\mathrm{Et}_{4} \mathrm{~Pb}\right){ }^{2}$

Yamamura et $\mathrm{al}^{3}{ }^{3}$ using the method of Yamamuchi et al, ${ }^{4}$ also identified the presence of $\mathrm{Et}_{2} \mathrm{~Pb}^{+2}$ in human urine after an acute intoxication by inhalation. The results of previous studies indicate that there is a correlation between the magnitude of exposure to $\mathrm{Et}_{4} \mathrm{~Pb}$ and the level of $\mathrm{Et}_{2} \mathrm{~Pb}^{+2}$ excretion in human urine. ${ }^{2}$

Bolanowska and Garczyński examined the metabolism of $\mathrm{Et}^{4} \mathrm{~Pb}$ in rabbits and suggested that the metabolism of this compound proceeds through the formation of $\mathrm{Et}_{2} \mathrm{~Pb}^{+2}$ as an intermediate metabolite. Arai et al confirmed this suggestion and showed that $\mathrm{Et}_{2} \mathrm{~Pb}^{+2}$ is the predominant metabolite excreted in rabbit urine. ${ }^{6} 7$

The aim of the current work was to establish the dynamics of $\mathrm{Et}_{2} \mathrm{~Pb}^{+2}$ excretion in rabbit urine according to the dose and method of administering $\mathrm{Et}_{4} \mathrm{~Pb}$. For comparison, the dynamics of $\mathrm{Et}_{2} \mathrm{~Pb}^{+2}$ excretion in the urine of subjects occupationally exposed to $\mathrm{Et}_{4} \mathrm{~Pb}$ were also examined.

\section{Materials and methods}

ANIMAL STUDY

Investigations were made on 17 male rabbits of Dan-

Accepted 21 July 1986 ish breed with an average body weight of $3.5 \mathrm{~kg}$. The animals were given one dose each of $\mathrm{Et}_{4} \mathrm{~Pb}$, of two different amounts, using two different methods, intravenous and intragastric. $E t_{4} \mathrm{~Pb}$ was administered through the auricular vein using a microsyringe in doses of $12 \mathrm{mg} / \mathrm{kg}$ and $3 \mathrm{mg} / \mathrm{kg}$. The same doses were administered intragastrically in gelatinous capsules (Parke-Davis, Detroit, Michigan) filled with $\mathrm{Et}_{4} \mathrm{~Pb}$. Rabbits were also exposed through the respiratory tract for five hours in a toxicological chamber to $\mathrm{Et}_{4} \mathrm{~Pb}$ at a concentration of $200 \mu \mathrm{g} / \mathrm{m}^{3}$ in the air. The concentration was checked every hour by taking activated carbon air samples. For the determination of $\mathrm{Et}_{4} \mathrm{~Pb}$, a modified dithizone method (M Dobecki, unpublished data) was used.

After exposure to $\mathrm{Et}_{4} \mathrm{~Pb}$, the rabbits were kept in metabolic cages and after one, two, three, five, seven, 14 , and 30 days, 24 hour urine samples were collected. Total lead $(\mathrm{Pb}-\mathrm{U})$ and $\mathrm{Et}_{2} \mathrm{~Pb}^{+2}$ were determined in the urine by atomic absorption spectrometry (AAS). ${ }^{1}$ The control group consisted of four rabbits of the same breed.

\section{HUMAN STUDY}

A group of three workers employed by a petrol company and who added $\mathrm{Et}_{4} \mathrm{~Pb}$ to petrol was also studied. The following procedure was applied to this group. The selected workers were removed for 10 days from the work area in which they were exposed to $\mathrm{Et}_{4} \mathrm{~Pb}$. Then for two days they returned to their work area, and hence exposure, and subsequently were again withdrawn from exposure to $\mathrm{Et}_{4} \mathrm{~Pb}$. Urine samples were taken during the first two days of 




Fig 1 Mass spectrum of pure $\mathrm{Et}_{4} \mathrm{~Pb}$.

exposure to $\mathrm{Et}_{4} \mathrm{~Pb}$ and on the five days after it. The total lead and the $\mathrm{Et}_{2} \mathrm{~Pb}^{+2}$ levels were determined ing the urine by AAS, ${ }^{1}$ the results being corrected to the average specific gravity of the urine. Atmospheries? samples were taken in the breathing zone of the work ers with Casella individual sampling tubes. The $\mathrm{Et}_{4} \mathrm{Pt}$ concentration in the atmosphere of the individua $\bar{r}$. work areas was determined by a modified dithizone method (M Dobecki, unpublished data). The controh group was composed of individuals of the same sex as those occupationally exposed the $\mathrm{Et}_{4} \mathrm{~Pb}$.

Pure $\mathrm{Et}_{4} \mathrm{~Pb}$ was obtained by vacuum distillation of an ethyl fluid containing about $60 \%$ of the pure com pound. The purity of the $\mathrm{Et}_{4} \mathrm{~Pb}$ obtained was

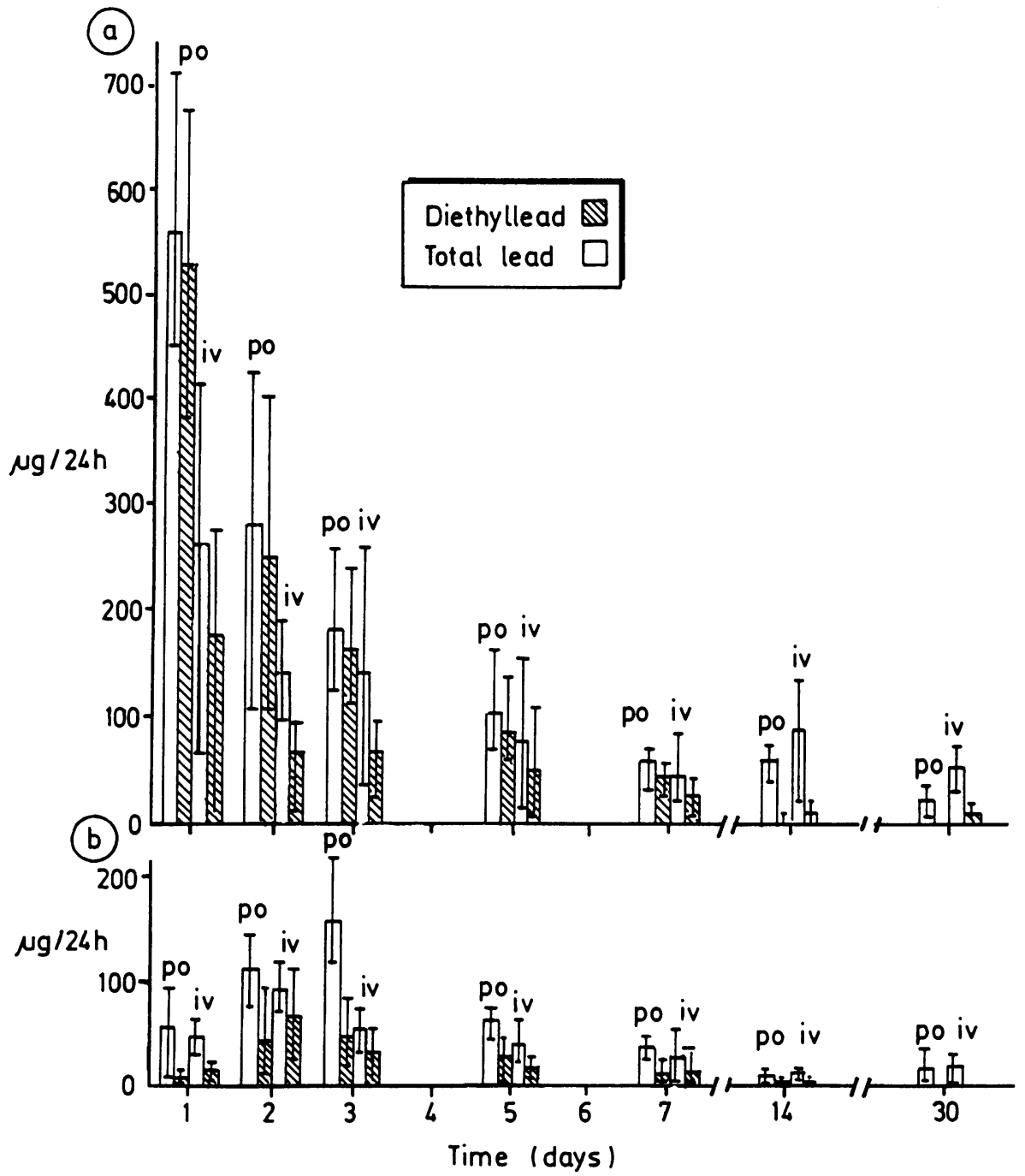

Fig 2 Dynamics of diethyllead and total lead excretion in rabbit urine after administration of $E t_{4} P b$. (a) $12 \mathrm{mg} / \mathrm{kg}$ dose of $E t_{4} P b$ and (b) $3 \mathrm{mg} / \mathrm{kg}$ dose of $E t_{4} P b$. 
Table 1 Percentage of total lead excreted in rabbit urine after 30 days of observation according to the dose and method of $\mathrm{Et}_{4} \mathrm{~Pb}$ administration

\begin{tabular}{|c|c|c|c|c|c|}
\hline \multirow[b]{2}{*}{ Dose of $E t_{4} \mathrm{~Pb}(\mathrm{mg} / \mathrm{kg})$} & \multirow{2}{*}{$\begin{array}{l}\text { Method of administration } \\
E t_{4} P b\end{array}$} & \multicolumn{2}{|c|}{ Total Pb level } & \multicolumn{2}{|l|}{$E t_{2} \mathrm{~Pb}^{+2}$} \\
\hline & & $\mu g / 30$ Days & $\%$ Of dose & $\mu g / 30$ Days & $\%$ Of dose \\
\hline $12 / 7 \cdot 7^{*}$ & $\begin{array}{l}\text { Intragastric } \\
\text { Intravenous }\end{array}$ & $\begin{array}{r}1278.01 \\
817 \cdot 68\end{array}$ & $\begin{array}{r}10 \cdot 6(16 \cdot 6)^{*} \\
6 \cdot 2(10 \cdot 6)^{*}\end{array}$ & $\begin{array}{r}1076 \cdot 51 \\
396 \cdot 18\end{array}$ & $\begin{array}{l}9 \cdot 0(13.9)^{*} \\
3 \cdot 3(5 \cdot 14)^{*}\end{array}$ \\
\hline $3 / 1 \cdot 9^{*}$ & $\begin{array}{l}\text { Intragastric } \\
\text { Intravenous }\end{array}$ & $\begin{array}{l}433 \cdot 04 \\
280 \cdot 47\end{array}$ & $\begin{array}{r}14 \cdot 4(22 \cdot 8)^{*} \\
9 \cdot 3(14 \cdot 8)^{*}\end{array}$ & $\begin{array}{l}130 \cdot 04 \\
135 \cdot 48\end{array}$ & $\begin{array}{l}4 \cdot 4(6 \cdot 53)^{*} \\
4 \cdot 1(7 \cdot 1)^{*}\end{array}$ \\
\hline
\end{tabular}

${ }^{*}$ Dose of $\mathrm{Et}_{4} \mathrm{~Pb}$ in terms of inorganic lead.

confirmed by mass spectrometry (fig 1 ) and analysis of the physical and chemical properties of the compound.

\section{Results}

Figure 2 shows the dynamics of $\mathrm{Et}_{2} \mathrm{~Pb}^{+2}$ and $\mathrm{Pb}-\mathrm{U}$ excretion after intragastric and intravenous administration of $\mathrm{Et}_{4} \mathrm{~Pb}$ according to dose.

After the intragastric administration of a $12 \mathrm{mg} / \mathrm{kg}$ dose of $\mathrm{Et}_{4} \mathrm{~Pb}$ (fig 2a), excretion of $\mathrm{Et}_{2} \mathrm{~Pb}^{+2}$ in the urine was observed which varied with respect to time.

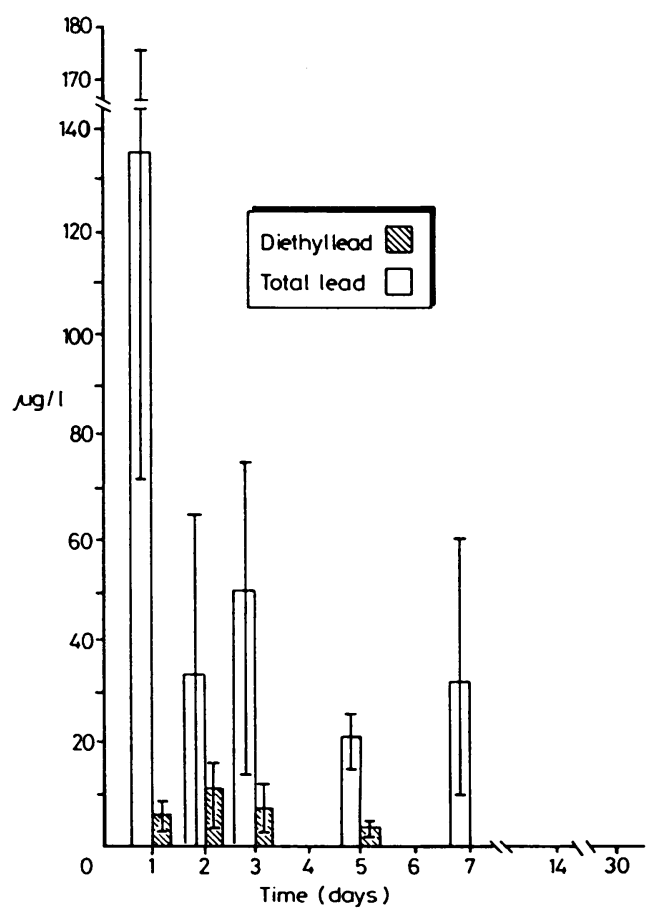

Fig 3 Dynamics of diethyllead and total lead in rabbit urine after a five hour exposure to $\mathrm{Et}_{4} \mathrm{~Pb}$ at a concentration of $200 \mu \mathrm{g} / \mathrm{m}^{3}$ in air.
During the first seven days after administration of $\mathrm{Et}_{4} \mathrm{~Pb}, \mathrm{Et}_{2} \mathrm{~Pb}^{+2}$ constituted from $70 \%$ to $90 \%$ of the total lead excreted in the rabbit urine. Maximum $\mathrm{Et}_{2} \mathrm{~Pb}^{+2}$ excretion was recorded on the first day after administration of $\mathrm{Et}_{4} \mathrm{~Pb}$, and after 30 days only trace quantities of this metabolite were in the urine. During the 30 days of observation, $\mathrm{Et}_{2} \mathrm{~Pb}^{+2}$ constituted $70 \%$ of the total lead excreted in the urine.

After intravenous administration of the same dose of $\mathrm{Et}_{4} \mathrm{~Pb}, \mathrm{Et}_{2} \mathrm{~Pb}^{+2}$ excretion was lower. During the first seven days this metabolite constituted about $50 \%$ of the total $\mathrm{Pb}$ excreted with the urine, but the maximum $\mathrm{Et}_{2} \mathrm{~Pb}^{+2}$ was again recorded on the first day after administration of $\mathrm{Et}_{4} \mathrm{~Pb}$. After 30 days only small quantitites were found in the urine. Over the whole 30 day period, only about $40 \%$ of the total lead was excreted in the form of $\mathrm{Et}_{2} \mathrm{~Pb}^{+2}$ in the urine.

After the administration of a $3 \mathrm{mg} / \mathrm{kg}$ dose (fig $2 \mathrm{~b}$ ), the excretion of $\mathrm{Et}_{2} \mathrm{~Pb}^{+2}$ did not vary so much between the intragastric and the intravenous methods. During the 30 days of observation, excreted $\mathrm{Et}_{2} \mathrm{~Pb}^{+2}$ constituted about $40 \%$ of the total lead excreted with urine. It should be emphasised, however, that for both the intragastric and intravenous methods of administration, maximum excretion of this metabolite in the urine was observed during the first three days after administration of $\mathrm{Et}_{4} \mathrm{~Pb}$. Table 1 shows the data concerning total lead excretion during the 30 days of observation according to the dose and method of administration. The intragastric method results in a total lead excretion in the urine proportional to the dose. Moreover, during the 30 days of observation the largest quantity of $\mathrm{Et}_{2} \mathrm{~Pb}^{+2}$ in relation to the dose and level of total lead was excreted after introducing a large dose intragastrically.

Figure 3 shows the dynamics of $\mathrm{Et}_{2} \mathrm{~Pb}^{+2}$ and total lead excretion in rabbit urine after a five hour exposure to $\mathrm{Et}_{4} \mathrm{~Pb}$ at a concentration of $200 \mu \mathrm{g} / \mathrm{m}^{3}$ in the air. Maximum $\mathrm{Et}_{2} \mathrm{~Pb}^{+2}$ excretion was recorded on the second day after exposure, and on this day the metabolite constituted about $20 \%$ of total lead excreted in the urine. On the seventh day after the end of exposure, only trace quantities of this metabolite 
Table 2 Numerical values of $\mathrm{Et}_{2} \mathrm{~Pb}^{+2}$ to total lead ratio in rabbit urine after administration of $\mathrm{Et}_{4} \mathrm{~Pb}$

\begin{tabular}{|c|c|c|c|c|c|c|c|c|}
\hline \multirow{2}{*}{$\begin{array}{l}\text { Method of administration of } \\
\mathrm{Et}_{4} \mathrm{~Pb}\end{array}$} & \multirow{2}{*}{$\begin{array}{l}\text { Dose of } E t_{4} P b \\
(\mathrm{mg} / \mathrm{kg})\end{array}$} & \multicolumn{7}{|c|}{ Days after administration } \\
\hline & & 1 & 2 & 3 & 5 & 7 & 14 & 30 \\
\hline Intragastric & $\begin{array}{r}12 \\
3\end{array}$ & $\begin{array}{l}0.90 \\
0 \cdot 13\end{array}$ & $\begin{array}{l}0 \cdot 89 \\
0 \cdot 39\end{array}$ & $\begin{array}{l}0.90 \\
0 \cdot 29\end{array}$ & $\begin{array}{l}0.87 \\
0.41\end{array}$ & $\begin{array}{l}0 \cdot 77 \\
0 \cdot 31\end{array}$ & $\begin{array}{l}0 \cdot 04 \\
0 \cdot 24\end{array}$ & $\begin{array}{l}0.04 \\
0.01\end{array}$ \\
\hline Intravenous & $\begin{array}{r}12 \\
3\end{array}$ & $\begin{array}{l}0.65 \\
0 \cdot 28\end{array}$ & $\begin{array}{l}0.47 \\
0.68\end{array}$ & $\begin{array}{l}0.46 \\
0.56\end{array}$ & $\begin{array}{l}0.61 \\
0.42\end{array}$ & $\begin{array}{l}0.53 \\
0.47\end{array}$ & $\begin{array}{l}0 \cdot 10 \\
0 \cdot 12\end{array}$ & $\begin{array}{l}0.13 \\
0.05\end{array}$ \\
\hline Inhalation & $200 \mu \mathrm{g} / \mathrm{m}^{3}$ & 0.04 & $0 \cdot 11$ & $0 \cdot 15$ & $0 \cdot 14$ & * & $*$ & * \\
\hline
\end{tabular}

Results in $\mu \mathrm{g} \mathrm{Pb} / \mathrm{l}$ were corrected according to 24 hour excretion in urine.

Ratio of mean values $(n=3)$.

*Traces of $\mathrm{Et}_{2} \mathrm{~Pb}^{+2}$ found in urine.

were found in the urine, and constituted a much smaller fraction of the total lead excreted in the urine.

Table 2 shows the ratio of $\mathrm{Et}_{2} \mathrm{~Pb}^{+2}$ to total lead in rabbit urine according to the doses and methods of $\mathrm{Et}_{4} \mathrm{~Pb}$ exposure used in these experiments. The numerical value of this ratio throughout almost a week for a dose of $12 \mathrm{mg} / \mathrm{kg} \mathrm{Et} \mathrm{t}_{4} \mathrm{~Pb}$ introduced intragastrically is close to one. The reduced ratio observed after the administration of the $3 \mathrm{mg} / \mathrm{kg}$ dose of $\mathrm{Et}_{4} \mathrm{~Pb}$ may indicate the further dealkylation of $\mathrm{Et}_{2} \mathrm{~Pb}^{+2}$ to ionic lead.

After the intravenous introduction of a $12 \mathrm{mg} / \mathrm{kg}$ dose of $\mathrm{Et}_{4} \mathrm{~Pb}$, the numerical value of the ratio is lower than after the intragastric administration, which may be due to the lower activity of the liver in the $\mathrm{Et}_{4} \mathrm{~Pb}$ dealkylation. The value of this ratio after intravenous administration is less affected by the size of the dose, which could be connected with the limited ability of the liver to dealkylate a high dose of $\mathrm{Et}_{4} \mathrm{~Pb} . \mathrm{S}$

In the experiments designed to evaluate exposure of $\oplus$ the rabbits to $\mathrm{Et}_{4} \mathrm{~Pb}$ by inhalation the degree of $\mathrm{Et}_{4} \mathrm{~Pb} V$ dealkylation to $\mathrm{Et}_{2} \mathrm{~Pb}^{+2}$ is much reduced, which could be connected both with the low dose and the accelerated dealkylation process.

Analysis of variance (three factor experiment with repeated measures) served to identify the importance of the dose and intragastric administration on the efficiency of $\mathrm{Et}_{4} \mathrm{~Pb}$ metabolism into $\mathrm{Et}_{2} \mathrm{~Pb}^{+2}(\mathrm{p}<$ $0.05)$. Also, an important interdependence $(\mathrm{p}<0.05)$ O between the dose and method of administration was observed.

The application of the Newman test ${ }^{8}$ indicated sta tistically significant differences in $\mathrm{Et}_{2} \mathrm{~Pb}^{+2}$ excretion 2 in rabbit urine in the days subsequent to inhalation $\overrightarrow{\vec{B}}$

Table 3 Dynamics of $\mathrm{Et}_{2} \mathrm{~Pb}^{+2}$ excretion in urine of workers occupationally exposed to $\mathrm{Et}_{4} \mathrm{~Pb}$

\begin{tabular}{|c|c|c|c|c|}
\hline \multirow[b]{2}{*}{ Observation time (days) } & \multirow{2}{*}{$\begin{array}{l}\text { Concentration of } \mathrm{Et}_{4} \mathrm{~Pb} \text { in } \\
\text { the air }\left(\mathrm{mg} / \mathrm{m}^{3}\right)\end{array}$} & \multicolumn{2}{|l|}{$\mu g P b / l$} & \multirow{2}{*}{$\frac{E t_{2} \mathrm{~Pb}^{+2}}{\text { Total lead }}$} \\
\hline & & $P b-U$ & $E t_{2} P b^{+2}$ & \\
\hline $\begin{array}{l}1 \\
2 \\
3 \\
4 \\
5 \\
6 \\
7\end{array}$ & $\begin{array}{l}0.156 \\
0.147 \\
- \\
- \\
- \\
-\end{array}$ & $\begin{array}{c}52 \cdot 7 \\
61 \cdot 49 \\
129 \cdot 76 \\
101 \cdot 53 \\
42.1 \\
66.1 \\
44.8\end{array}$ & $\begin{array}{r}4 \cdot 50 \\
13 \cdot 44 \\
26 \cdot 24 \\
7 \cdot 60 \\
2 \cdot 57 \\
6.85 \\
6.86\end{array}$ & $\begin{array}{l}0.08 \\
0.21 \\
0.21 \\
0.08 \\
0.06 \\
0.06 \\
0.15\end{array}$ \\
\hline $\begin{array}{l}1 \\
2 \\
3 \\
4 \\
5 \\
6 \\
7\end{array}$ & $\begin{array}{l}0.274 \\
0.350 \\
- \\
- \\
- \\
-\end{array}$ & $\begin{array}{c}61.49 \\
103.0 \\
116.8 \\
79.3 \\
42.9 \\
72.0 \\
76.64\end{array}$ & $\begin{array}{r}8 \cdot 64 \\
6 \cdot 50 \\
18 \cdot 46 \\
10 \cdot 12 \\
3.50 \\
5 \cdot 13 \\
8.90\end{array}$ & $\begin{array}{l}0.14 \\
0.06 \\
0.15 \\
0.12 \\
0.08 \\
0.07 \\
0.12\end{array}$ \\
\hline $\begin{array}{l}1 \\
2 \\
3 \\
4 \\
5 \\
6 \\
7\end{array}$ & $\begin{array}{l}0.450 \\
0.810 \\
- \\
- \\
- \\
-\end{array}$ & $\begin{array}{c}49 \cdot 15 \\
190 \cdot 51 \\
135.7 \\
110 \cdot 1 \\
53.3 \\
113.46 \\
14.9\end{array}$ & $\begin{array}{c}7 \cdot 2 \\
15 \cdot 36 \\
4 \cdot 28 \\
25 \cdot 0 \\
5 \cdot 70 \\
27 \cdot 20 \\
4 \cdot 00\end{array}$ & $\begin{array}{l}0.14 \\
0.05 \\
0.03 \\
0.22 \\
0.10 \\
0.23 \\
0.26\end{array}$ \\
\hline
\end{tabular}


exposure to $\mathrm{Et}_{4} \mathrm{~Pb}(\mathrm{p}<0.05)$. On the second day after administration of $\mathrm{Et}_{4} \mathrm{~Pb}$ a considerably higher excretion of this metabolite in urine, by comparison with results from the other days of observation, was noted.

Table 3 shows the results of the study of $\mathrm{Et}_{2} \mathrm{~Pb}^{+2}$ excretion in the urine of subjects occupationally exposed to $\mathrm{Et}_{4} \mathrm{~Pb}$; total lead concentrations in urine are given after the subtraction of the concentrations of lead found in the control group $(24.8 \pm 11 \mu \mathrm{g}$ $\mathrm{Pb} / \mathrm{l})$. The lead found in the urine is thus only an effect of exposure to $\mathrm{Et}_{4} \mathrm{~Pb}$. The percentage of $\mathrm{Et}_{2} \mathrm{~Pb}^{+2}$ in proportion to total lead is variable. The increase of $\mathrm{Et}_{2} \mathrm{~Pb}^{+2}$ excretion in urine is considerably influenced, however, by a high concentration of $\mathrm{Et}_{4} \mathrm{~Pb}$ in the air. It should be emphasised that in the urine of exposed workers, even five days after the end of exposure, considerable $\mathrm{Et}_{2} \mathrm{~Pb}^{+2}$ excretion was observed, especially in the workers exposed to high concentrations of $\mathrm{Et}_{4} \mathrm{~Pb}$. The numerical values of the $\mathrm{Et}_{2} \mathrm{~Pb}^{+2}$ (total lead ratio) varied between 0.05 and 0.29 .

\section{Discussion}

The results presented show the relations between the dose and method of $\mathrm{Et}_{4} \mathrm{~Pb}$ administration and the excretion of $\mathrm{Et}_{2} \mathrm{~Pb}^{+2}$ in rabbit urine. After the intravenous administration of a $12 \mathrm{mg} / \mathrm{kg}$ dose of $\mathrm{Et}_{4} \mathrm{~Pb}$, the results obtained for excreted total lead and $\mathrm{Et}_{2} \mathrm{~Pb}^{+2}$ during the first week of observation are about the same as those of Arai et al. ${ }^{3467}$ Total lead excreted with urine after 24 hours constituted about $3 \%, 70 \%$ of which was in the form $\mathrm{Et}_{2} \mathrm{~Pb}^{+2}$. Prolongation of the observation time of the excretion dynamics of $\mathrm{Et}_{4} \mathrm{~Pb}$ metabolites to 30 days (fig 2) permitted the detection of $\mathrm{Et}_{2} \mathrm{~Pb}^{+2}$ in rabbit urine at the level of $7 \mu \mathrm{g} / 24$ hours.

An important result was to show that $\mathrm{Et}_{2} \mathrm{~Pb}^{+2}$ is also a dominant metabolite after intragastric administration of $\mathrm{Et}_{4} \mathrm{~Pb}$. Moreover, the metabolic capacity of this compound in rabbits is higher after intragastric than after intravenous administration (table 2). The liver is the main site of $\mathrm{Et}_{4} \mathrm{~Pb}$ dealkylation to $\mathrm{Et}_{3} \mathrm{~Pb}^{+}$ (triethyllead). ${ }^{56}$ This metabolite is labile and undergoes a change to $\mathrm{Et}_{2} \mathrm{~Pb}^{+2}$ which is excreted into the bile. A further stage of dealkylation to ionic lead takes place in the intestines. Over $90 \%$ of the $\mathrm{Et}_{4} \mathrm{~Pb}$ dose is excreted in the rabbit faeces in the form of ionic lead, with minimal excretion of $\mathrm{Et}_{3} \mathrm{~Pb}^{+}$and $\mathrm{Et}_{2} \mathrm{~Pb}^{+2}$. The $\mathrm{Et}_{4} \mathrm{~Pb}$ and $\mathrm{Et}_{3} \mathrm{~Pb}^{+}$biotransformation probably proceeds from hydroxylation of carbon with the participation of monoxigenase and further dealkylation processes occur, probably without the presence of enzymes. 9

It appears from our studies that the smaller the dose of $\mathrm{Et}_{4} \mathrm{~Pb}$, the smaller the amount of $\mathrm{Et}_{2} \mathrm{~Pb}^{+2}$ metabolite excreted in the urine. Even in rabbits exposed by inhalation to $\mathrm{Et}_{4} \mathrm{~Pb}$ concentrations exceeding twice the TLV, however, the method described was successful in tracing this metabolite in urine after five days. The metabolite constituted only a small percentage of total lead, which indicates that at low doses, dealkylation of $\mathrm{Et}_{2} \mathrm{~Pb}^{+2}$ to ionic lead takes place quickly.

Previous studies ${ }^{2}$ and those presented in table 3 indicate that the magnitude of the $\mathrm{Et}_{4} \mathrm{~Pb}$ dose absorbed by workers during working hours determines the rate of $\mathrm{Et}_{2} \mathrm{~Pb}^{+2}$ excretion. This metabolite could be determined in urine even after the fifth day in the case of workers exposed to the lowest concentration of $\mathrm{Et}_{4} \mathrm{~Pb}$.

To sum up the research results, it should be emphasised that $\mathrm{Et}_{2} \mathrm{~Pb}^{+2}$ in urine is a new indicator of exposure to $\mathrm{Et}_{4} \mathrm{~Pb}$. A strong correlation was found between the concentration of $\mathrm{Et}_{4} \mathrm{~Pb}$ in the air and excretion of $\mathrm{Et}_{2} \mathrm{~Pb}^{+2}$ in the urine. ${ }^{2}$

The studies carried out with regard to various applied doses and methods of $\mathrm{Et}_{4} \mathrm{~Pb}$ administration to rabbits show that these animals are suitable experimental material for the interpretation of results on man.

\section{References}

1 Turlakiewicz Z, Jakubowski M, Chmielnicka J. Determination of diethyllead in urine by flameless atomic absorption spectrophotometry. Br J Ind Med 1985;42:63-6.

2 Turlakiewicz Z, Chmielnicka J. Diethyllead as a specific indicator of occupational exposure to tetraethyllead. $\mathrm{Br} \mathrm{J}$ Ind $\mathrm{Med}$ 1985;42:682-5.

3 Yamamura Y, Arai F, Yamamuchi H. Urinary excretion pattern of triethyllead, diethyllead, and inorganic lead in tetraethylead poisoning. Industrial Health 1981;19:125-31.

4 Yamamuchi H, Arai F, Yamamura Y. Determination of triethyllead diethyllead and inorganic ions in urine by hydride generation-flameless atomic absorption spectrophotometry. Industrial Health 1981;19:115-25.

5 Bolanowska W, Garczyński H. Metabolism czteroetylku olowiu u królików. Med Pracy 1968;3:235-43.

6 Arai F, Yamamura Y, Yoshida M. Excretion of triethyllead diethyllead and inorganic lead after injection of tetraethyllead in rabbits. Japanese Journal of Industrial Health 1981; 23:496-504.

7 Arai F, Yamamura Y, Yamamuchi H, Yoshida M. Biliary excretion of diethyllead after injection of tetraethyllead in rabbits. Japanese Journal of Industrial Health 1983;25:175-80.

8 Winer BJ. Statistical principles in experimental design. New York: McGraw-Hill, 1962:337-44.

9 Grandjean P, Nielsen T. Organolead compounds: environmental health aspects. Residue Rev 1979;72:98-148. 